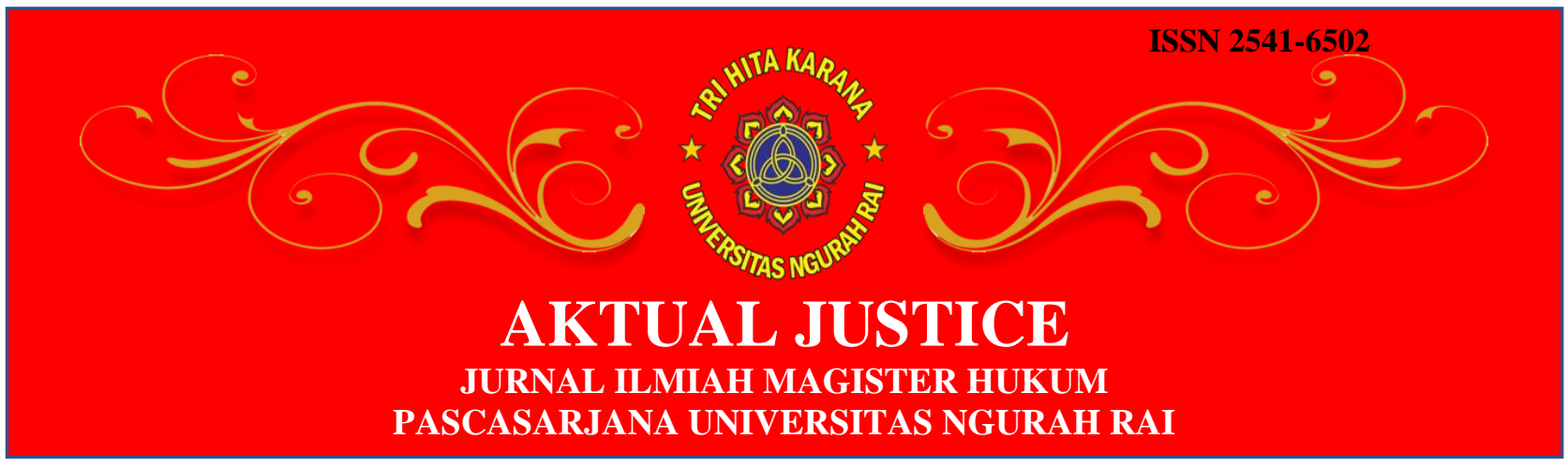

\title{
KEDUDUKAN INSTRUKSI PRESIDEN REPUBLIK INDONESIA NOMOR 1 TAHUN 1991 TENTANG PENYEBARLUASAN KOMPILASI HUKUM ISLAM DALAM SISTEM HUKUM KEWARISAN INDONESIA
}

\author{
Fajar Sugiantoㄹ, Denny Ardhi Wibowo², Tomy Michael ${ }^{3}$ \\ 1Dosen Tetap Program Studi Hukum Bisnis Universitas Agung Podomoro, \\ e-mail: fajar.sugianto@podomorouniversity.ac.id \\ ${ }^{2}$ Laboran Laboratorium Hukum Bisnis Universitas Agung Podomoro, \\ e-mail: denny.wibowo@podomorouniversity.ac.id \\ ${ }^{3}$ Dosen Tetap Fakultas Hukum Universitas 17 Agustus 1945 Surabaya, \\ e-mail: tomy@untag-sby.ac.id
}

\begin{abstract}
The Islamic inheritance law system is one of the inheritance law systems that apply in Indonesia. Presidential Instruction 1/1991 is a legal instrument that makes Islamic law a positive law in Indonesia, however, the development of the constitutional system and the legal system in Indonesia has undergone very rapid changes since the reform era. This raises new legal problems in the implementation of the Compilation of Islamic Laws considering that the position of Presidential Instruction 1/1991 in the statutory system is not known as statutory regulation.

In the aspect of binding power, the Presidential Instruction cannot be applied to the public because it does not have general binding power and only binds inwardly against officials with a lower position in 1 (one) institution. Even so, the existence of Presidential Instruction 1/1991 is still recognized to this day considering that its substance was formed through a joint decision between the Minister of Religion and the Chief Justice of the Supreme Court. Thus, the Compilation of Islamic Law binds religious court judges who are under the environment of the Supreme Court. Judges can use the Compilation of Islamic Law as a legal basis for resolving disputes that occur between Muslim communities.

Keywords: Presidential Instruction 1/1991, source of law, Indonesian inheritance legal system

\begin{tabular}{c}
\hline Abstrak \\
\hline Sistem hukum kewarisan Islam merupakan salah satu sistem hukum kewarisan yang \\
berlaku di Indonesia. Inpres 1/1991 merupakan instrumen hukum yang menjadikan hukum islam \\
sebagai hukum positif di Indonesia, akan tetapi perkembangan sistem ketatanegaraan dan sistem \\
perundang-undangan di Indonesia telah mengalami perubahan yang sangat pesat sejak era
\end{tabular}
\end{abstract}


reformasi. Hal ini menimbulkan problem hukum baru dalam pemberlakuan Kompilasi Hukum Islam mengingat kedudukan Inpres 1/1991 dalam sistem perundang-undangan tidak dikenal sebagai peraturan perundang-undangan.

Dalam aspek kekuatan mengikat, Inpres tersebut tidak dapat diberlakukan untuk umum karena tidak mempunyai kekuatan mengikat umum dan hanya bersifat mengikat ke dalam terhadap pejabat yang berkedudukan lebih rendah pada 1 (satu) institusi. Kendatipun demikian eksistensi Inpres 1/1991 hingga hari ini masih diakui keberadaannya mengingat substansinya dibentuk melalui keputusan bersama antara Menteri Agama dengan Ketua Mahkamah Agung. Sehingga, Kompilasi Hukum Islam mengikat hakim-hakim peradilan agama yang berada di bawah lingkungan Mahkamah Agung. Para hakim dapat menggunakan Kompilasi Hukum Islam sebagai dasar hukum untuk menyelesaikan sengketa yang terjadi diantara masyarakat yang beragama Islam.

Kata Kunci: Inpres 1/1991, sumber hukum, sistem hukum kewarisan Indonesia.

\section{Pendahuluan}

Dalam tinjauan sejarah, dinamika pemikiran hukum Islam di Nusantara telah menunjukan satu fenomena cukup transformatif dan remedialis dan mewartakan sebuah dinamika yang hidup dan cukup maju. Mendasar pada sifat contiunity and change, geliat pemikiran ini telah mengalami, bukan hanya tambal sulam ide, tetapi seperti bola, terus menggelinding dan melaju membentuk karakter-karakternya yang unik di dalamnya. Upaya pemikiran hukum Islam ini telah banyak dimulai jauh sebelum kawasan Nusantara ini terpecah menjadi banyak negara, yang pada perkembangannya biasa disebut Asia Tenggara, dengan Indonesia sebagai core sirkumtansinya. Menarik untuk memotret ulang narasi sejarah perkembangan, yang kurang lebih paling awal, pemikiran hukum islam nusantara secara paralel dan genesis dalam perkembangan doktrin hukum islam modern di Indonesia.

Keberadaan hukum islam di Indonesia, sejatinya melalui perjalanan sejarah yang panjang. Secara genealogis, perlu dilihat latar belakang atau akar sejarahnya, yakni pada masuknya islam untuk kali pertama secara massal di Indonesia. Karena itu, sebelum mengurai mengenai keberadaan dan perkembangan pemikiran hukum Islam, ada 
baiknya dijelaskan secara singkat beberapa teori masuknya Islam di Nusantara ini. Pembahasan mengenai hal ini lebih diurgensikan untuk mengetahui sejauhmana implikasi watak eksklusif Islam pertama itu terhadap perkembangan hukum Islam.

Berkenaan dengan hal tersebut, Azyumadi Azra mengemukakan bahwa, setidaknya terdapat 3 (tiga) teori berkenaan dengan masuknya islam ke Indonesia. Kesatu, Islam datang ke Indonesia pada abad ke 1 hijriyah atau ke 7 masehi dari Hadramaut ke daratan Aceh. Selanjutnya, teori tersebut pernah dikukuhkan di sebuah seminar masuknya islam di Indonesia tahun 1962 di Medan dan didukung oleh Naqub, Hamka, Hasjmi, Yunus, dan beberapa sejarawan asing yakni Niemann, Holander, Crawfurd, dan Vetsh. Walaupun demikian, para sejarawan di Indonesia juga dengan cukup terbuka memberi catatan tentang adanya komunikasi yang intens antara muslim yang berasal dari India Timur dengan masyarakat Indonesia layak pula untuk diperhitungkan dalam menelisik masuknya islam di Indonesia. ${ }^{1}$

Agaknya teori ini semata didasarkan pada keinginan emosional para sejarawan islam yang ingin memastikan keberadaan islam di Indonesia sebagai agama masyarakat yang otentik, bukan periferal atau sinkretis, sebagaimana yang dituduhkan oleh kebanyakan penulis Barat. Mematrik hal ini, Abdul Rahman Haji Abdullah memaparkan bahwa pada abad ke 7 Masehi lahirlah kegiatan bisnis antara pedagang Arab dengan masyarakat Indonesia. Alasan ini sedikit berbeda dengan analisis dari sejarawan Barat yang juga mengakui teori ini. Keyzer misalnya, yang menganggap kedatangan islam di Indonesia berasal dari kelompok syafi'iyah (orang bermadzhab Syafi'i) berkebangsaan Mesir karena dinilai sama dengan madzhab yang dikembangkan oleh muslim Indonesia.

${ }^{1}$ Azra, A. (1989). Perspektif Islam Asia Tenggara. Jakarta: YOI. h. Vii-viii. 
Sedangkan Niemann dan De Holander hanya menyebut Hadramaut (bukan Mesir), yang juga bermazhab Syafiei, sebagai sumber datangnya Islam. Bagaimanapun teori ini cukup gagap untuk memberi kontitum dan jawaban pasti jika dihadapkan pada persoalan krusial proses konversi agama dan Islam-isasi di dalamnya. Yakni, para pedagang ini datang untuk semata hanya berdagang, dan tidak mungkin perannya berubah atau berganda dengan sekaligus melakukan dakwah agama. Dengan melihat sifat ketidakmungkinan ini, dengan demikian bisa simpulkan bahwa ketika itu proses konversi agama dan Islam-isasi belum bisa dikatakan telah terjadi. $^{2}$

Teori kedua adalah kedatangan islam di Indonesia beraal dari Malabar dan Gujarat dan bukan dari Arab maupun Persia. Hal tersebut sebagaimana dikemukakan oleh Drewes yang kemudian disempurnakan oleh Hurgronje dalam buku yang berjudul L"arabie et les Indes Neerlendaises, atau Revue de l"Histoire des Religius," Teori ini mengaskan bahwa, orang Arab yang beraliran Syafi'iyah bermigrasi ke India dan kemudian datang dan masuk ke Indonesia dengan membawa ajaran yang dianut sejak dari Arab yang oleh sejarawan disebut sebagai muslim deccan. Oleh karena itu, para muslim Deccan inilah yang datang sebagai penyebar Islam pertama di kawasan ini. Baru kemudian disusul oleh para Sayyid dan Syarîf yang menyelesaikan proses konversi agama ini dengan "membaptis" diri mereka menjadi pemuka gereja (priest) maupun raja. Periode inilah yang kemudian ditetapkan sebagai embrio dari lahirnya islam di Indonesia pada abad ke 12 masehi.

Berkenaan dengan hal tersebut, Snouck Hurgronje sendiri mendasarkan pandangannya pada beberapa pertimbangan, yaitu tidak

2 Abdullah, A.R.H. (1990). Pemikiran Umat Islam di Nusantara: Sejarah Dan Perkembangan Hingga Abad Ke 19. Kuala Lumpur : Dewan Bahasa dan Pustaka. h. 24.

3 Suryanegara, A.M. (1998). Menemukan Sejarah: Wacana Pergerakan Islam di Indonesia. Bandung: Mizan. h. 75. 
cukupnya bukti-bukti yang menyatakan beberapa penduduk Arab datang ke Indonesia untuk menyebarkan islam. Kedua, eksistensi kegiatan perdagangan antara pedagang India dengan masyarakat Indonesia telah ada sejak lama. TeraKompilasi Hukum Islamr, adanya bukti kuat berupa inskripsi yang tersimpan di daerah Sumatera menandakan terciptanya relasi yang cukup kuat antara pedagang dari Gujarat dengan masyarakat Sumatera. ${ }^{4}$

Ketiga, teori yang menyatakan bahwa Islam datang dari Benggali (Bangladesh), karena kebanyakan orang terkemuka di Pasai adalah orang Benggali atau keturunan mereka. Islam muncul pertama kali di Semenanjung Malaya adalah dari arah pantai Timur, bukan dari Barat (Malaka), yaitu melalui Kanton, Phanrang (Vietnam), Leran, dan Trengganu. Secara doktrin ajaran (mazhab), Islam di Semenanjung sama dengan Islam di Phanrang, sementara elemen prasasti yang ditemukan di Trengganu juga mirip dengan prasasti di Leran. Teori yang dikembangkan oleh Fatimi ini dikritik oleh Drewes dengan mengatakan bahwa bukti-bukti yang ada, terutama terkait dengan prasasti ini merupakan "perkiraan liar". Hal ini masih ditambah dengan adanya kenyataan bahwa mazhab hukum yang dominan di Bengkali adalah Hanafi, bukan Syafie ${ }^{\circ}{ }^{5}$

Bertitik tolak dari hal tersebut, keberadaan agama islam di Indonesia dipertegas dengan hidup dan berkembangnya hukum islam dalam masyarakat Indonesia. Atas dasar itu, eksistensi hukum Islam di Indonesia selalu mengambil dua bentuk, yakni hukum normatif yang diimplementasikan secara sadar oleh umat Islam, dan hukum formal yang dilegislasikan sebagai hukum positif bagi umat Islam. Pertama menggunakan pendekatan kultural, sementara yang kedua menggunakan

4 Ibid., h. 77.

${ }^{5}$ Azra, A. (1994). Jaringan Ulama Timur Tengah dan Kepulauan Nusantara Abad XVII $\mathcal{E}$ XVIII. Bandung : Mizan. h. 25-26. 
pendekatan struktural. Hukum Islam dalam bentuk kedua itu pun proses legislasinya menggunakan dua cara. Pertama, hukum Islam dilegislasikan secara formal untuk umat Islam, seperti Peraturan Pemerintah Nomor 28 Tahun 1977 tentang Perwakafan, UU Nomor 17 Tahun 1999 tentang Penyelenggaraan Ibadah Haji, dan Undang-Undang Nomor 38 Tahun 1999 tentang Pengelolaan Zakat. Kedua, materi-materi hukum Islam diintegrasikan ke dalam hukum nasional tanpa menyudutkan hukum Islam secara formal, seperti Undang-Undang Nomor 1 Tahun 1974 tentang Perkawinan dan Undang-Undang Nomor 7 tahun 1989 tentang Peradilan Agama. Selain itu, ada Instruksi Presiden Nomor 1 Tahun 1991 tentang Penyebarluasan Kompilasi Hukum Islam (Inpres 1/1991).

Membicarakan tentang masalah Kompilasi Hukum Islam pada dasarnya adalah membicarakan salah satu aspek dari hukum Islam di Indonesia dan bilamana kita membicarakan tentang hukum Islam di Indonesia, kita akan memasuki sebuah perbincangan yang kompleks sekalipun hukum islam berada pada kedudukan yang sangat strategis dalam etalase hidup bermasyarakat yang didominasi umat islam hingga dewasa ini. 6

Dalam pandangan yang lebih umum, sistematika Kompilasi Hukum Islam dibagi atas 3 (tiga) jenis, yaitu hukum perkawinan islam yang menjadi bagian dari buku kesatu, hukum waris yang diatur dalam buku kedua dan hukum wakaf yang dituangkan ke dalam buku ketiga. Secara teknis, tiap-tiap buku berisi bab-bab yang kemudian diderivasi ke dalam beberapa pasal dan ayat. Berkaitan dengan hal tersebut Hasballah Thaib mengemukakan bahwa dilihat dari sisi historis, perkembangan syari'at islam di Indonesia mengalami fase stagnasi dibandingkan dengan negara-

6 Abdurrahman. (2001). Kompilasi Hukum Islam di Indonesia. Cet. 3. Jakarta: Akademika Pressindo. h. 1-2. 
negara di jazirah Arab. ${ }^{7}$ Hal tersebut disebabkan oleh keyakinan mayoritas umat islam untuk lebih memilih metode taqlid dari para ulama untuk menyelesaikan masalah yang ada.

Selanjutnya adalah bahwa kehidupan sosial dan politik dewasa ini selalu mengundang polemik dan perselisihan serta seringkali dibenturkan pada masalah kenegaraan yang nampaknya hendak dipisahkan dari paradigma keagamaan. Terakhir, adanya skeptisme terhadap fiqh di kalangan masyarakat muslim Indonesia, karena dianggap sebagai buah dari olah pikir akal manusia yang tidak mungkin mempunyai kebenaran absolut layaknya firman atau hukum yang diturunkan langsung sebagai wahyu Allah. ${ }^{8}$

Menilik uraian di atas, jelas bahwa Inpres 1/1991 tentang Penyebarluasan Kompilasi Hukum Islam adalah instrumen hukum yang menjadikan hukum islam sebagai hukum positif di Indonesia. Namun demikian, perkembangan sistem ketatanegaraan dan sistem perundangundangan di Indonesia telah mengalami perubahan yang sangat pesat sejak era reformasi. Oleh karena itu, timbul problem hukum baru dalam pemberlakuan Kompilasi Hukum Islam terutama yang menyangkut pengaturan kewarisan berdasarkan hukum Islam mengingat kedudukannya dalam sistem perundang-undangan telah mengalami perubahan. Berpokok pangkal dari hal tersebut, secara akademik diajukan pertanyaan sebagai berikut: Bagaimana Kedudukan Instruksi Presiden Republik Indonesia Nomor 1 Tahun 1991 Tentang Penyebarluasan Kompilasi Hukum Islam Dalam Sistem Hukum Kewarisan Indonesia?

7 Thaid, H. (2002). Tajdid Reaktualisasi dan Elastisitas Hukum Islam, Makalah disajikan pada acara seminar para hakim dan panitera Pengadilan Agama se Sumatera Utara Medan: 12 Juni 2002. h. 12.

8 Ibid. h. 13. 


\section{Metode Penelitian}

Tulisan ini menggunakan metode penelitian yuridis normatif atau penelitian hukum normatif. Penelitian normatif adalah "Penelitian Hukum Normatif merupakan penelitian hukum yang dilakukan dengan cara meneliti bahan pustaka atau data sekunder". 9 "Penelitian hukum normatif disebut juga penelitian hukum doktrinal. Menurut Peter Mahmud Marzuki, penelitian hukum normatif adalah suatu proses untuk menemukan suatu aturan hukum, prinsip-prinsip hukum, maupun doktrin-doktrin hukum guna menjawab isu hukum yang dihadapi". 10

\section{Hasil Dan Pembahasan}

Kompilasi Hukum Islam disusun disusun melalui Keputusan Bersama antara Ketua Mahkamah Agung dengan Menteri Agama yang kemudian didukung dan disambut secara baik oleh kalangan ulama dan tokoh agama. Karena itu pula, sejatinya Kompilasi Hukum Islam digali dari akar pemikiran para ulama yang kemudian didiskusikan untuk menemukan kesepahaman guna disepakati bersama agar menghasilkan suatu ijma' yang nantinya digunakan sebagai sumber pembentukan hukum dan perundang-undangan oleh negara. ${ }^{11}$ Konsensus atau ijma' para ulama tersebut dalam sistem perundang-undangan nasional dapat dikategorikan sebagai hukum tidak tertulis yang diakui keberadaannya namun tidak dipaksanakan keberlakuannya. Oleh karena itu, perlu dilakukan positivisasi ke dalam perundang-undangan yang berlaku secara formal di Indonesia. Dalam konteks itu, penyusunan Kompilasi Hukum Islam di Indonesia terdiri atas 2 (dua) fase, yakni fase inventarisasi materi pokok

9 Soekanto, S. \& Mamudji, S. (2003). Penelitian Hukum Normatif : Suatu Tinjauan Singkat. Jakarta: Raja Grafindo Persada, h. 13.

${ }^{10}$ Marzuki, P.M. (2010). Penelitian Hukum, Jakarta: Kencana Prenada. h. 35

11 Basri, C.H. (1999). Kompilasi Hukum Islam Dalam Sistem Hukum Nasional. Jakarta: Logos Wacana Ilmu. h. 8. 
yang menjadi muatan dalam Kompilasi Hukum Islam dan fase pembentukan Kompilasi Hukum Islam dengan menuangkan materi yang digali dari sumber hukum islam ke dalam peraturan perundang-undangan yang berlaku secara formil di Indonesia.

Lahirnya Kompilasi Hukum Islam secara historis menegaskan bahwa hukum islam merupakan hukum yang sejak lama ada dan bersemayam dalam sendi-sendi kehidupan masyarakat muslim Indonesia. Kedua, tuntutan pemeluk agama islam di Indonesia yang menghendaki adanya hukum yang diadopsi dari hukum islam yang berbasis pada keyakinan keagamaan agar ada kepastian hukum dalam penyelenggaraan kegiatan yang bernuansa islami. Ketiga, keinginan kuat dari para ulama untuk membentuk suatu hukum tertulis yang sesuai dengan standar perundang-undangan sehingga keberadaan hukum islam mempunyai legalitas dan legitimasi dari negara dan teraKompilasi Hukum Islamr, keberadaan Kompilasi Hukum Islam merupakan transformasi hukum tidak tertulis ke dalam hukum positif di Indonesia. ${ }^{12}$

Berkaitan dengan kedudukan Kompilasi Hukum Islam dalam sistem hukum di Indonesia setidaknya dapat dijelaskan melalui 4 (empat) hal, yakni 1) kedudukan Kompilasi Hukum Islam diakui secara konstitusional bahkan diakui pula menurut Pancasila sebagaimana termaktub dalam konsiderans (menimbang) Inpres 1/1991; 2) legalisasi Kompilasi Hukum Islam dilakukan melalui instrumen hukum berupa instruksi Presiden yang kemudian ditindaklanjuti dengan keputusan Menteri Agama; 3) digali dari sumber hukum islam yang telah dikaji dan disepakati oleh para ulama sesuai dengan kondisi masyarakat muslim Indonesia; 4) legalitas dan legitimasi Kompilasi Hukum Islam diakui oleh para hakim Peradilan Agama sehingga dapat dijadikan dasar dan rujukan

12 Abdullah, A.G. (1994). Pengantar Kompilasi Hukum Islam Dalam Tata Hukum Indonesia. Cet. 1. Jakarta: Gema Insani Press. h. 63. 
serta dipedomani dalam memutuskan sengketa tertentu yang terjadi antar umat islam. ${ }^{13}$

Selanjutnya, Kompilasi Hukum Islam sebagai rujukan utama dalam penyelesaian setiap sengketa yang timbul antara umat islam didasarkan atas beberapa faktor, yakni 1) kedudukan Kompilasi Hukum Islam sebagai produk hukum yang secara formil ditetapkan oleh negara; 2) substansi Kompilasi Hukum Islam dirumuskan dalam ijma' para ulama yang telah menjadi panutan umat; 3) kultur masyarakat muslim yang didasarkan pada keyakinan beragama dan 4) adanya kemudahan bagi masyarakat muslim Indonesia dalam menyelesaikan problematikan hukum dan sosial dengan bersandar pada Kompilasi Hukum Islam. ${ }^{14}$

Selain faktor-faktor di atas, faktor lain yang menjadi dasar kuatnya penerimaan Kompilasi Hukum Islam di masyarakat adalah karena proses perumusan Kompilasi Hukum Islam dilakukan dengan melibatkan banyak pihak dan beberapa pemangku kepentingan (stake holders). Terlebih, beberapa pihak yang terlibat merupakan elit-elit yang dianggap mempunyai kapasitas keilmuan yang cukup sehingga setiap argumentasi yang dirumuskan menjadi demikian akurat kebenarannya.

Namun demikian, sebagaimana proses islamisasi nusantara, keberadaan Kompilasi Hukum Islam di Indonesia seringkali menemui hambatan dan kesulitan. Hal ini dikarenakan usia Kompilasi Hukum Islam yang masih belia dan kurang diketahui oleh masyarakat muslim secara luas. Oleh karena itu, faktor sosialisasi menjadi salah satu problem utama mengapa Kompilasi Hukum Islam belum menjadi pedoman sepenuhnya oleh seluruh kalangan umat muslim. Kedua, persoalan yang muncul di tengah-tengah masyarakat muslim Indonesia adalah perbedaan madzhab dan aliran diantara tokoh agama panutan umat, terlebih tokoh agama yang

\footnotetext{
13 Abdurrahman, Op.Cit., h. 9-10

14 Ibid. h. 15
} 
tidak terlibat dalam proses perumusan Kompilasi Hukum Islam sehingga hal tersebut memberikan pengaruh pula bagi para pengikutnya untuk mengesampingkan Keberadaan Kompilasi Hukum Islam dalam berhukum. Ketiga, seringkali terjadi konflik yang mendasar antara normanorma yang diatur dalam Kompilasi Hukum Islam dengan budaya masyarakat setempat dan hukum adat mereka, terutama ketika berkaitan dengan hukum waris yang tentu sangat beragam berdasarkan tempat, suku, etnis dan sebagainya. ${ }^{15}$

Selanjutnya, berkenaan dengan Kompilasi Hukum Islam secara fungsional, dalam pemikiran sederhana Hasan Basri menyebut sebagai proses pembentukan hukum yang bermuara pada kodifikasi. Ia mengemukakan bahwa, Kompilasi Hukum Islam merupakan awal dari adanya kodifikasi hukum yang dibentuk oleh negara melalui instrumen undang-undang yang nantinya menjadi karya besar yang berasal dari sumbangsih pemikiran cendekiawan muslim untuk memenuhi tuntutan dan harapan masyarakat muslim Indonesia. ${ }^{16}$

Berbeda dengan pendapat tersebut Bustanul Arifin menegaskan bahwa Kompilasi Hukum Islam merupakan kumpulan pendapat para intelektual muslim mengenai fiqh yang menyangkut permasalahan seharihari dari umat islam Indonesia. Oleh karena itu, adanya Kompilasi Hukum Islam bukanlah sebuah kodifikasi yang nantinya akan merubah dengan yang baru sama sekali. ${ }^{17}$ Landasan hukum yang mendasari keberlakuan Kompilasi Hukum Islam adalah Inpres 1/1991 yang secara langsung memberikan perintah kepada Menteri Agama untuk mensosialisasikan kepada seluruh masyarakat dan institusi negara. Dengan demikian, sesuai dengan fungsinya maka instruksi Presiden tersebut hanya sebatas perintah

${ }^{15}$ Basri, C.H., Loc.Cit.

${ }^{16} \mathrm{Ibid}$. h. 15

${ }^{17}$ Arifin, B. (1985). Kompilasi: Fiqh Dalam Bahasa Undang-Undang. Jurnal Pesantren. Vol. II, No. 2, September. h. 28. 
untuk mensosialisasikan Kompilasi Hukum Islam. Selanjutnya, Inpres 1/1991 ditindaklanjuti dengan Kepmenag 154/1991 sebagai respons atas Inpres 1/1991 yang dalam konsideran menguraikan hal-hal sebagai berikut:

a. Instruksi Presiden Republik Indonesia Nomor 1 Tahun 1991 tanggal 10 Juni 1991 memerintahkan Kepada Menteri Agama untuk menyebarluaskan Kompilasi Hukum Islam untuk digunakan oleh Instansi Pemerintah dan oleh masyarakat yang memerlukannya;

b. Bahwa penyebarluasan Kompilasi Hukum Islam tersebut perlu dilaksanakan dengan sebaik-baiknya dan dengan penuh tanggung jawab.

c. Bahwa oleh karena itu perlu dikeluarkan Keputusan Menteri Agama Republik Indonesia tentang pelaksanaan Intruksi Presiden Republik Indonesia Nomor 1 Tahun 1991 tanggal 10 Juni 1991.

Memperhatikan hal-hal di atas, setidaknya ada 3 (tiga) hal yang perlu digarisbawahi dalam Inpres 1/1991 dan Kepmenag 154/1991, yaitu:

1) Instruksi untuk mensosialisasikan Kompilasi Hukum Islam bagi masyarakat yang membutuhkan sebagai rujukan resmi dalam penyelesaian sengketa umat islam di Indonesia;

2) Kompilasi Hukum Islam merupakan penegasan dari berlakunya undang-undang yang berkaitan dengan hukum islam seperti undangundang perkawinan dan sebagainya;

3) Mempertegas ruang lingkup berlakunya yakni pada institusi negara yang terkait dengan keagamaan seperti peradilan agama dan bagi masyarakat muslin yang membutuhkan rujukan resmi yang bersumber dari hukum islam. ${ }^{18}$

Berpokok pangkal dari 3 (tiga) hal di atas, jelas bahwa negara

18 Ali, Z. (2006). Hukum Islam: Pengantar Hukum Islam di Indonesia. Jakarta: Sinar Grafika. h. 61-62. 
mengakui keberadaan hukum islam yang dianggap sakral bagi sebagian besar masyarakat yang beragama islam. Oleh karena itu, negara mengakomodasi kebutuhan tersebut sehingga telah memenuhi unsur sosiological validity dalam pembentukan Kompilasi Hukum Islam di Indonesia. Selanjutnya, berkenaan dengan sumber utama dalam perumusan Kompilasi Hukum Islam sekurang-kurangnya ada 6 (enam) sumber sebagai berikut:

1) Produk hukum lembaga legislatif maupun eksekutif seperti UU 22/1946, UU 32/1954, UU 1/1974, UU 7/1898, PP 9/1975, PP 28/1977;

2) Putusan-putusan hakim Pengadilan Agama yang berkaitan dengan masalah waris dan penyelesaian konflik dengan hukum waris adat;

3) Kajian akademik dari perguruan tinggi islam seperti Institut Agama Islam melalui lokakarya, seminar dan sebagainya;

4) Pendapat hukum dari berbagai ahli yang diinventarisasi dari berbagai daerah seperti Surabaya, Mataram, Ujung Pandang, Bandung dan Palembang;

5) Notulensi hasil studi komparatif di negara-negara yang berbasis islam seperti Republik Maroko, Mesir serta Turki; dan

6) Hasil diskusi para ulama dari seluruh Indonesia yang berkumpul di Jakarta pada tangga 2 sampai dengan 6 Februari tahun 1989.19

Enam sumber di atas oleh Andi Syamsu Alam disebut sebagai law in abstracto, ${ }^{20}$ karena dianggap telah banyak menyelesaikan persoalan umat islam ketika berselisih dengan sesama orang islam meskipun sumber yang berupa putusan hakim sejatinya secara teoritis disebut sebagai law in concretto. Dalam dokumen historis, jauh sebelum adanya Inpres 1/1991 ada

${ }^{19}$ Ibid. h. 66.

${ }^{20}$ Alam, A.S. Eksistensi Rancangan Undang-Undang Tentang Hukum Terapan Peradilan Agama Bidang Perkawinan Bagi Peradilan Agama, Makalah disampaikan pada Seminar RUU tentang Hukum Terapan Peradilan Agama Bidang Perkawinan, Padang tanggal 11 Juni 2005, h. 1. 
beberapa pihak yang mendalami hukum tata negara yang meminta poositivisasi hukum islam dilakukan dengan membuat peraturan pemerintah, peraturan Presiden dan bahkan undang-undang. Sebab, instrumen hukum tersebut merupakan jenis peraturan yang tepat dalam membentuk hukum positif yang disarikan dari hukum islam. ${ }^{21}$

Berkenaan dengan sifat Inpres 1/1991 dalam perspektif ilmu hukum tata negara dan hukum administrasi, disebutkan bahwa instruksi Presiden merupakan instrumen hukum yang bersifat konkret dan individual serta terjadi dalam hubungan hierarkis dalam satu institusi. Artinya bahwa, kekuatan mengikat yang terkandung dalam instruksi Presiden hanya berlaku pada individu yang berkedudukan lebih rendah dalam satu institusi. Hal tersebut berbeda dengan sifat mengikat peraturan perundang-undangan seperti peraturan presiden, peraturan pemerintah dan undang-undang yang berlaku dan mempunyai kekuatan mengikat umum (erga omnes). ${ }^{22}$ Atas dasar itu, adressat dari Inpres 1/1991 adalah Menteri Agama secara individual, sehingga ditindaklanjuti melalui Kepmenag 154/1991.23 Mencermati hal demikian, maka Kompilasi Hukum Islam berkedudukan sebagai berikut:

1) Kompilasi Hukum Islam adalah produk dari positivisasi hukum islam di Indonesia yang bukan merupakan jenis peraturan perundangundangan sebagaimana ditegaskan dalam Pasal 7 ayat (1) UU 12/2011.

2) Kompilasi Hukum Islam dijadikan rujukan secara sukarela di lembaga Peradilan Agama dan menjadi dasar hukum tetap yang melandasi putusan-putusan hakim Pengadilan Agama.

3) Inpres 1/1991 tidak mempunyai kekuatan mengikat umum sebagaimana peraturan perundang-undangan. Dengan demikian, setiap

21 Muttaqien, D. (1999). Peradilan Agama dan Kompilasi Hukum Islam dalam Tata Hukum Indonesia. Yogyakarta: UII Press. h. 45.

22 Latif, A dan Ali, H., (2011). Politik Hukum. Cet. 2. Jakarta: Sinar Grafika. h. 68.

${ }^{23}$ Ibid. h. 48. 
orang khususnya hakim tidak wajib berpedoman pada Kompilasi Hukum Islam kendatipun juga tidak dilarang untuk merujuk pada Kompilasi Hukum Islam

4) Inpres 1/1991 hanya ditujukan untuk Menteri Agama sebagai pembantu Presiden dalam penyelenggaraan pemerintahan negara. Karena itu, addresat dari Inpres 1/1991 adalah khusus bagi Menteri Agama. ${ }^{24}$

Selanjutnya, mencermati proses positivisasi hukum islam di Indonesia, Nasrun Harun sebagaimana dikutip oleh Habiburrahman mengemukakan bahwa, upaya atau keinginan untuk melakukan perubahan atau bahkan penggantian terhadap Kompilasi Hukum Islam sangatlah kuat jika dilihat dari hasil penjaringan aspirasi dari masyarakat muslim Indonesia. Hal tersebut dikarenakan bentuk produk hukum dari Kompilasi Hukum Islam adalah isntruksi Presiden yang secara akademik dan praktis sama sekali bukan merupakan peraturan perundang-undangan sehingga tidak mempunyai kekuatan yang sama dengan peraturan perundang-undangan, hal demikian tentu memunculkan ketidakpastian hukum baru dalam pengimplementasian hukum islam di Indonesia. Justru, kondisi demikian memunculkan persepsi bahwa upaya positivisasi hukum islam dilaksanakan secara tidak serius karena mengerdilkan makna positivisasi tersebut dengan membentuk produk hukum yang tidak mempunyai daya paksa sebagaimana peraturan perundang-undangan. Di sisi lain, adanya keinginan merubah atau mengganti Kompilasi Hukum Islam muncul dari kalangan yang beraliran non Syafi'I yang menganggap Kompilasi Hukum Islam terlalu bercorak Syafi'iyyah, padahal madzhab dari pemikiran islam dalam bidang fiqh di Indonesia tidak hanya beraliran Syafi'i namun ada pula yang bermadzhab Maliki, Hanbali, Hanafi dan bahkan Syi'ah. Beberapa aliran tersebut tidak hanya dianut oleh

24 Manan, B. (2003). Teori Dan Politik Konstitusi. Yogyakarta: Fakultas Hukum Universitas Islam Indonesia. h. 211. 
masyarakat dan pemikir islam saja, bahkan sebagian hakim Pengadilan Agama pun juga menganut beberapa madzhab tersebut. ${ }^{25}$

Menilik uraian dalam penjelasan di atas, penulis berpendapat bahwa umat Islam Indonesia mempunyai hak yang dijamin oleh konstitusi untuk memperjuangkan tegaknya hukum islam di Indonesia dengan cara melakukan positivisasi hukum islam secara terkodifikasi dalam tingkat undang-undang melalui jalur kekuasaan seperti menjadi anggota legislatif yang nantinya diberikan kewenangan untuk membentuk undang-undang bersama-sama dengan pemerintah. Selain itu, upaya untuk mempositivisasi hukum islam dapat dilakukan di lembaga-lembaga pendidikan dan dakwah serta penyampaian aspirasi melalui ruang-ruang diskusi publik atau dapat juga melalui pengujian peraturan perundangundangan yang dianggap bertentangan dengan nilai-nilai keagamaan khususnya islam sebagaimana telah dijamin dalam Pasal 29 UndangUndang Dasar Negara Republik Indonesia Tahun 1945.

Untuk mengatasi polemik baru mengenai eksistensi Inpres 1/1991, penulis juga berpendapat bahwa seyogyanya Presiden bersama-sama dengan Dewan Perwakilan Rakyat Republik Indonesia mulai merumuskan undang-undang yang materi muatannya mengatur mengenai hukum islam secara keseluruhan baik yang berkaitan dengan hukum keluarga maupun hukum ekonomi syari'ah. Artinya bahwa, pembentuk undang-undang melakukan kodifikasi terhadap hukum islam yang menjadi bagian dari sistem hukum yang berlaku di Indonesia di samping hukum adat dan hukum barat. Hal tersebut penting, mengingat keberadaan Inpres 1/1991 hanya sebatas instruksi dalam hubungan dinas antara atasan dengan bawahan yang dapat saja berlaku sekali selesai dan tidak berlaku secara

${ }^{25}$ Habiburrahman, Perkawinan Perempuan Muslimah Dengan Warga Negara Asing, Makalah disampaikan pada Seminar RUU tentang Hukum Terapan Peradilan Agama Bidang Perkawinan di IAIN Imam Bonjol Padang tanggal 11 Juni 2005, h. 6-7. 
terus menerus sebagaimana peraturan perundang-undangan yang sepanjang tidak dicabut atau dibatalkan oleh lembaga peradilan tetap berlaku dalam waktu yang tidak tertentu. Pemikiran demikian disandarkan pada legal problem solving guna memberikan jalan keluar bagi permasalahan hukum yang ada dalam pemberlakuan Kompilasi Hukum Islam di Indonesia agar dapat memberikan kepastian hukum bagi seluruh pihak baik hakim maupun masyarakat dan tentunya yang paling penting juga agar dapat memberikan keadilan bagi warga negara yang beragama Islam dalam menyelesaikan sengketa kewarisan Islam. Dengan demikian, kedudukan Instruksi Presiden Republik Indonesia Nomor 1 Tahun 1991 tentang Penyebarluasan Kompilasi Hukum Islam menjadi sumber hukum formal dalam sistem hukum Indonesia.

\section{Kesimpulan}

Berdasarkan uraian penjelasan di atas, disimpulkan bahwa Inpres 1/1991 merupakan produk hukum yang bersifat individual dan konkret serta berlaku dalam satu institusi secara vertikal antara atasan dan bawahan. Adapun produk hukum tersebut tidak dikenal sebagai peraturan perundang-undangan baik secara konseptual maupun secara normatif sebagaimana ditegaskan dalam Pasal 7 ayat (1) Undang-Undang Nomor 12 Tahun 2011 tentang Pembentukan Peraturan Perundang-Undangan.

Dalam aspek kekuatan mengikat, Inpres 1/1991 hanya bersifat mengikat ke dalam terhadap pejabat yang berkedudukan lebih rendah pada 1 (satu) institusi. Dengan demikian, instruksi presiden tersebut tidak dapat diberlakukan untuk umum karena tidak mempunyai kekuatan mengikat umum. Namun demikian, eksistensi Inpres 1/1991 hingga hari ini masih diakui keberadaannya mengingat substansi dari Kompilasi Hukum Islam yang menjadi isi dari instruksi presiden tersebut dibentuk melalui keputusan bersama antara Menteri Agama dengan Ketua 
Mahkamah Agung. Sehingga, Kompilasi Hukum Islam mengikat hakimhakim peradilan agama yang berada di bawah lingkungan Mahkamah Agung. Dengan demikian, hakim-hakim tersebut dapat menggunakan Kompilasi Hukum Islam sebagai dasar hukum untuk menyelesaikan sengketa yang terjadi diantara masyarakat yang beragama islam.

Atas dasar hal tersebut, kendatipun Inpres 1/1991 tidak termasuk dalam kategori peraturan perundang-undangan dan tidak mempunyai kekuatan mengikat umum sebagaimana undang-undang, namun kedudukannya didasarkan pada daya paksa yang lahir dari keyakinan dalam beragama Islam yang menjadi bagian dari sistem hukum kearisan Islam. Namun demikian, di masa yang akan datang penulis menyarankan agar Kompilasi Hukum Islam dibentuk menjadi undang-undang yang terkodifikasi dengan seluruh ketentuan yang disarikan dari prinsip atau nilai-nilai syari'at islam agar mempunyai kedudukan lebih kuat dalam sistem hukum di Indonesia.

\section{DAFTAR PUSTAKA}

\section{Buku}

Abdurrahman. (2001). Kompilasi Hukum Islam di Indonesia. Cet. 3. Jakarta: Akademika Pressindo.

Abdullah, A.G. (1994). Pengantar Kompilasi Hukum Islam Dalam Tata Hukum Indonesia. Cet. 1. Jakarta: Gema Insani Press.

Abdullah, A.R.H. (1990). Pemikiran Umat Islam di Nusantara: Sejarah Dan Perkembangan Hingga Abad Ke 19. Kuala Lumpur : Dewan Bahasa dan Pustaka.

Ali, Z. (2006). Hukum Islam: Pengantar Hukum Islam di Indonesia. Jakarta: Sinar Grafika.

Azra, A. (1989). Perspektif Islam Asia Tenggara. Jakarta: YOI. 
. (1994). Jaringan Ulama Timur Tengah dan Kepulauan Nusantara Abad XVII \& XVIII. Bandung: Mizan.

Basri, C.H. (1999). Kompilasi Hukum Islam Dalam Sistem Hukum Nasional. Jakarta: Logos Wacana Ilmu.

Latif, A dan Ali, H., (2011). Politik Hukum. Cet. 2. Jakarta: Sinar Grafika.

Manan, B. (2003). Teori Dan Politik Konstitusi. Yogyakarta: Fakultas Hukum Universitas Islam Indonesia.

Marzuki, P.M. (2010). Penelitian Hukum, Jakarta: Kencana Prenada.

Muttaqien, D. (1999). Peradilan Agama dan Kompilasi Hukum Islam dalam Tata Hukum Indonesia. Yogyakarta: UII Press.

Soekanto, S. \& Mamudji, S. (2003). Penelitian Hukum Normatif : Suatu Tinjauan Singkat. Jakarta: Raja Grafindo Persada.

Suryanegara, A.M. (1998). Menemukan Sejarah: Wacana Pergerakan Islam di Indonesia. Bandung: Mizan.

\section{Jurnal}

Arifin, B. (1985). Kompilasi: Fiqh Dalam Bahasa Undang-Undang. Jurnal Pesantren. Vol. II, No. 2, September.

\section{Makalah}

Alam, A.S. Eksistensi Rancangan Undang-Undang Tentang Hukum Terapan Peradilan Agama Bidang Perkawinan Bagi Peradilan Agama, Makalah disampaikan pada Seminar RUU tentang Hukum Terapan Peradilan Agama Bidang Perkawinan, Padang tanggal 11 Juni 2005.

Habiburrahman, Perkawinan Perempuan Muslimah Dengan Warga Negara Asing, Makalah disampaikan pada Seminar RUU tentang Hukum Terapan Peradilan Agama Bidang Perkawinan di IAIN Imam Bonjol Padang tanggal 11 Juni 2005.

Thaid, H. (2002). Tajdid Reaktualisasi dan Elastisitas Hukum Islam, Makalah disajikan pada acara seminar para hakim dan panitera Pengadilan Agama se Sumatera Utara Medan: 12 Juni 2002. 